\title{
MODERN RADIOTHERAPY TECHNIQUES
}

\author{
FRANJO CMREČAK ${ }^{1}$, IVA ANDRAŠEK ${ }^{1}$, MELIHA SOLAK MEKIĆ ${ }^{1}$, \\ MIRNA RAVLIĆ ${ }^{1}$ and LIDIJA BEKETIĆ-OREŠKOVIĆ ${ }^{1,2}$ \\ ${ }^{1}$ Division of Radiotherapy and Medical Oncology, University Hospital for Tumors, \\ Sestre milosrdnice University Hospital Center, Zagreb, Croatia; \\ ${ }^{2}$ Department of Clinical Oncology, School of Medicine University of Zagreb, Zagreb, Croatia
}

\section{Summary}

The aim of this review article is to present new sophisticated techniques in radiotherapy, which occurred due to the advancement of technology over the past few decades. The paper will provide insight into their advantages and disadvantages, the importance of diagnostic imaging modality, precise contouring, treatment planning and control of patients' position during radiation treatment. The transition from two-dimensional to three-dimensional radiotherapy has allowed contouring of target volume and organs at risk and accurate information on radiation dosage delivered. With a further desire for more precision and protection of healthy tissues, techniques such as intensity modulated radiotherapy (IMRT) and volumetric modulated arc therapy (VMAT) have been developed with the ability to modulate beam intensity. Quality imaging diagnostics is an infallible part of the modern radiotherapy. Image-guided radiotherapy (IGRT) and adaptive radiotherapy enable the delivery of high precision radiation to the target volume and spares organs at risk by correcting interfractional and intrafractional variations. Respiratory gating and tracking technique are useful for tumours that change their position during respiratory cycle. Stereotactic ablative radiotherapy (SABR) is a technique that uses highly conformal high-dose hypofractionated radiation to treat small tumours. In some indication such as the treatment of early stage non-small lung cancer, it competes with radical surgery. SABR is also an important therapeutic modality in the management of oligometastatic disease. This paper will briefly discuss proton therapy and its unique physical properties.

KEY WORDS: intensity-modulated radiation therapy, image-guided radiotherapy, volumetric modulated arc therapy, adaptive radiotherapy, stereotactic ablative radiotherapy, proton therapy

\section{Sažetak}

MODERNE METODE RADIOTERAPIJE

Cilj ovog preglednog rada je prikazati nove sofisticirane metode radioterapije koje su se razvile zahvaljujući napretku tehnologije unazad par desetljeća. Osvrnut ćemo se na njihove prednosti i nedostatke, važnost slikovne obrade, preciznog konturiranja, planiranja radioterapije i kontrole pozicije pacijenta tijekom radioterapije. Prijelaz s konvencionalne dvodimenzionalne na konformalnu trodimenzionalnu radioterapiju je omogućio konturiranje ciljnog volumena i organa od rizika te praćenje isporučene radioterapijske doze. Daljnjom željom za još većom preciznošću i poštedom zdravih tkiva razvile su se još naprednije tehnike poput radioterapije snopovima promjenjivog intenziteta (IMRT) i volumetrijski modulirane lučne terapije (VMAT) koje imaju mogućnost moduliranja intenziteta snopa. Kvalitetna slikovna dijagnostika je neizostavan dio moderne radioterapije. Radioterapija vođena slikom (IGRT) i adaptivna radioterapija omogućuju isporuku visokopreciznog zračenja na ciljni volumen i poštedu organa od rizika korigiranjem interfrakcionarnih i intrafrakcionarnih varijacija. Gating tehnika i tracking tehnika su korisne kod pomičnih tumora tijekom ciklusa disanja. Stereotaktička ablativna radioterapija (SABR) je tehnika koja koristi visokokonformalno, visokodozno hipofrakcionirano zračenje u liječenju malih tumora. U nekim indikacijama, kao npr. liječenje karcinoma nemalih stanica pluća ranog stadija, ova metoda može zamijeniti kirurški 
zahvat. Važan je terapijski modalitet u liječenju oligometastatske bolesti. U ovom radu će biti govora i o protonskoj terapiji i njenim jedinstvenim fizikalnim svojstvima.

KLJUČNE RIJEČI: radioterapija snopovima promjenjivog intenziteta, volumetrijski modulirana lučna terapija, slikom vođena radioterapija, adaptiona radioterapija, stereotaktička ablationa radioterapija, terapija protonima

\section{INTRODUCTION}

Radiotherapy is one of the cornerstones for treating oncological patients along with surgery and different systemic therapies; approximately $50 \%$ of cancer patients will require a radiotherapeutic treatment at some point (1). Depending on the cancer type, and stage of the disease, four types of radiotherapy can be discerned: curative, neoadjuvant, adjuvant and palliative. Radiotherapy can be performed as a single modality treatment, or it can be combined with other treatment modalities sach as chemotherapy, immunotherapy, hormonal therapy or surgery. The main mechanism of radiotherapy is to produce irreversible damages to the DNA molecule in malignant cells, by application of ionizing radiation. Radiotherapy is not only used in treating malignant diseases, but also in treating benign diseases such as: keloid scars, trigeminal neuralgia, acoustic schwannoma, pterygium, heterotopic ossification and arteriovenous malformation in the brain. In its beginnings, older radiotherapy techniques were less accurate and provided limited data on actual radiation dosage to the target volume and organs at risk. Rapid technological advances that occurred in the last thirty years enabled swift advancement of the procedure, as radiotherapy progressed from twodimensional conventional radiotherapy to threedimensional conformal radiotherapy (3D CRT). By using special CT/MR device and software, radiation oncologist can plan the radiotherapy and contour the tumour's volume and organs at risk, as well as provide precise information about delivered radiation dose. In conformal radiotherapy the radiation beam is shaped according to the contour of the target volume. With this technique overall radiation dose can be increased and healthy tissues remain spared with fewer side effects of the treatment. Further progress in technology represent more conformal and sophisticated radiotherapy techniques, known as: intensitymodulated radiation therapy (IMRT), volumetric modulated arc therapy (VMAT), stereotactic ablative radiotherapy (SABR), image guided radiation therapy (IGRT), proton therapy and adaptive radiotherapy.

\section{Intensity Modulated Radiation Therapy (IMRT)}

One of the more advanced forms of three-dimensional conformal radiotherapy is IMRT. The IMRT technology has been developed in the 1990s, and by the late 1990s it was commercially available in only the most advanced oncology centres. Development of this technology was enabled by sophisticated computers that control a linear accelerator and motorised multileaf collimators. In comparison with conformal 3D radiotherapy, IMRT has two key additional features: it uses beams that have changing dose intensity accross them during the radiotherapy and enables performance of computerised inverse planning. Modulation of beams is achieved by movement of multileaf collimators during the radiation process. The aim of this process is to bulid up the desired dose distribution. The modulation of the beams is achieved by generating beamlets of different sizes, which are shaped by the reposition of multileaf collimators. Result of using numerous modulated beams on the target volume is a delivery of highly conformal dose to the target volumes, and simultaneously maximal protection of nearby healthy tissues from the irradiation damage. High precision and a high level of conformity enables escalation of the dose and it additionally protects the healthy tissue. Two varieties of radiation techniques are possible in IMRT. First technique is segmental MLC technique or step and shoot technique (2). In this technique, every beam is divided into several segments with different positions of the collimator leaves. Radiation occurs only when leaves reach a new position. By adding up all segments, field of modulated intensity is created. Second technique is dynamic one, as radiation occurs continually, even during movement of collimator leaves. Modulation of the beam is achieved by variations in the speed and distance among the leaves (3).

Unlike classical forward planning, IMRT technology enables performance of computerised 
inverse planning method. During the process of forward planning, the physicists choose the energy of the beams, their directions, sizes, wedges and other parameters in order to obtain optimal dose distribution. In IMRT, the possible positions of collimator leaves are so numerous, that it would be too difficult for a physicist to choose the optimal combinations of beams and size of the segments. In inverse planning the computer system is provided by the informations about needed dose and its desired distribution on a target volume and about the dose limitations to the organs at risk. During the optimization process, the computer is trying to stay within given limitations and apply the calculated dose to the target volume by adjusting size and weight of every individual beam. It is important that the treatment planning system is supplied with complex and best possible parameters in order to produce the most optimal radiotherapy plan. After the optimization process and needed modulations, it is a clinical decision which plan is acceptable.

A study which compared forward and inverse planning in head and neck cancers has shown that inverse planning gives better results in covering target volume and a lesser dose on OAR. When compared to forward planning, inverse planning of radiotherapy in several cases of head and neck cancers enabled better protection of parotid glands (4).

By IMRT technique it is possible to simultaneously irradiate several target volumes, e.g. multiple brain metastasis (healthy brain tissue is spared). Different target volumes can simultaneously be treated by different fraction sizes and overall doses. For example, primary target volume (e.g. oropharyngeal cancer and pathological lymph node in the neck) can be irradiated to the overall dose, up to $60 \mathrm{~Gy}$ within 25 fractions, 2.4 Gy applied per fraction, while simultaneously covering secondary target volume (lymph nodes under risk), up to dose of 50 Gy within 25 fractions, 2 Gy applied per fraction (5). Better coverage of target volume and better conservation of organs at risks enables reirradiation by using IMRT technique. IMRT is especially valuable in treating head and neck cancers, due to proximity of numerous radiosensitive tissues/organs. IMRT reduces acute and late side effects of radiation when compared to classic 3D CRT. It has been shown that that IMRT can severely reduce the acute and late xerostomia (6). Nowadays, IMRT is used often in treating head and neck cancer, CNS tumours, prostate cancer, gynaecological tumours, esophageal and breast cancer. To summarize, advantages of IMRT are as following: greater accuracy in distribution and homogeneity of the dose, better protection of the critical organs, ability to give inhomogeneous dose throughout the various regions of the body, the possibility of dose escalation, higher conformity of radiotherapy (7). Possible downside of IMRT is higher cost; more expensive linear accelerator, sophisticated software, computer systems and networks, dosimetry, necessary investments in additional quality assurance and greater number of staff. Moreover, during the IMRT, the integrating dose of radiation is generally higher, which can result in greater possible risk of secondary malignancies (increased monitor units) (12). IMRT requires great precision in contouring of target volumes and the organs at risk, as well as more intensive quality assurance process $(7,8)$. However, although IMRT technique is complex and demanding, its advantages are significant and this method is higly recomended in the teatment of numerous malignant diseases (8).

\section{Volumetric Modulated Arc Therapy (VMAT)}

Radiotherapy was affected by technological advances in the last several decades, new imaging techniques and treatment planning systems were introduced and linear accelerators were developed. This development was initially started by a need for higher radiation dose on target volume and at the same time conservation of the organs at risk, which resulted in better tolerance of the radiation treatment with lower rate of acute and late side effects. High conformity, distribution of inhomogeneous dose and dose escalation is enabled by IMRT technique. Futher technology advancement represents the development of rotationbased technologies like VMAT and tomotherapy. VMAT was developed in 2007 and just like the IMRT, it enables very high distribution of the conformal dose; however, unlike the IMRT, it has three additional parameters, which can be modified during the radiation process. During the radiation process gantry rotates of up to 360 degrees and has the ability to modify the rotation's speed. It simultaneously enables variation of collimators' leaf translation and the dose rate (9). This enables VMAT to have several more beam entry angles, which consequently reduces the duration of the radiation and fewer number of monitor units, in comparison with the IMRT (10). According to Ber- 
telsen's study, where IMRT and single arc VMAT's plans for treatment of oropharyngeal and hypopharyngeal cancer were compared, the results showed equal or better coverage of target volume, with better protection of OAR while using VMAT algorithm. VMAT technique was associated with reduced number of monitor units by $8.5 \%$ per fraction and $35 \%$ of reduction in treatment duration (11). Similar results were shown by numerous other studies with different malignant deseases, e.g. cervical cancer, prostate cancer and brain tumours. VMAT resulted in better protection of OAR. Additionally, significant and constant difference between IMRT and VMAT is the reduced number of monitor units and a shorter treatment duration time in VMAT. Some studies have shown some equivalent results in comparison between IMRT and VMAT. Studies that compared VMAT and 3D CRT technique, have shown that VMAT has the superiority in administration of homogeneous dose and OAR protection (10). In both techniques, VMAT and IMRT, have been reported an increase in low dose radiation to surrounding healthy tissue. This increases the risk of secondary tumours and it is estimated that the incidence of secondary tumour could increased from 1 to $1.75 \%$ on patients who live on for 10 years (12).

\section{Image Guided Radiotherapy (IGRT)}

From it's very beginning, radiotherapy relied on radiological imaging techniques. Due to the technological advances and development of 3DCRT and IMRT, it became particularly important to display target volume during the radiation as accurate as possible. By doing so, one ensures that higher dose can be applied to the target volume with the protection of the healthy tissues. Nowadays, different diagnostic imaging can be used, such as: UZV, CT, MRI and PET/CT. Recent technological advancements enabled integration of some of those diagnostic imaging with the linear accelerator. Traditionally, portal imaging is used for the control of patients' position during the radiation process. Later on, Electronic Portal Imaging Device or EPID came into use, which is attached to linear accelerator and provides a digital image of better quality and contrast in comparison with portal imaging. EPID produces images of high quality when depicting bone structures; however, it produces poor images of soft tissues. Due to that fact, it is considered unessential if the tumour is not near or not in the bones; however, it still gives valuable information about the patient's position.

New technologies such as cone-beam CT provide a better contrast of soft tissues. During the radiation process, which usually takes up for weeks, there is a possibility of great variation in the position of patient and in possible size and location of target volumes, between fractions and even during the fraction itself. The most important factor is a precise positioning of the patient, in order to achieve accuracy and reproducibility. For thit purpose, skin markers, immobilization masks and pillows, fixators and vacuum mattresses can be used. Despite these aids, variations among fractions can still be significant. The treatment position of the patient should be regulary checked and if necessary, the reposition before the treatment should be done (13). Those variations in treatment volumes positions can be more significant by certain tumors, such as lung cancer or by abdominal tumors. In order to achieve escalation of treatment dose and reducing the dose on OAR, IGRT can enable todetect and remove these variations. This is a necessary process in modern highly accurate radiation techniques such as IMRT (14). IGRT is important because it detects movements of organs between the fractions. It has been shown that esophagus, for example, can drastically change its position in a lateral direction due to the peristalsis (15). The position of prostate can be also changed during the radiotherapy treatment. This organ movements can be influenced by different factors, such as the fullness ofrectum (14). The radiation of paraaorthic lymph nodes requires attention on possible movements of the kidneys (14).

During the radiotherapy of head and neck cancers, patients can have side effects such as: mucositis, nausea and vomiting, which can result in a drastic loss of body mass, which in turn results in anatomical differences that are seen on cone beam CT. All structures are then moved towards the centre so as a result skin and parotids are more exposed to radiation (16). During the radiotherapy of radiosensitive tumours, e.g. lymphomas, it is possible that tumour drastically losses volume and consequently radiosensitive organs in proximity of target volume could receive higher radiation dosage. Imaging during the radiation therapy can discover a progression of the cancerous mass, and by doing so spare the patient of undergoing unnecessary radiation. It is possible that intrafractional variations such as patient moving and mo- 
bility of internal organs such as lungs, kidneys and stomach take place alongside with interfractional variations. During the breathing, lung tumour can move up to $3 \mathrm{~cm}$, which necessitates a greater margin and additionally irradiates a huge portion of healthy tissues, which decreases the treatment's accuracy. To solve this problem, technique known as respiratory gating had been developed. In this technique, the tumour is treated only in a particular position whilst breathing (17). Another technique of irradiating mobile tumours is known as the tracking method, where irradiating beam follows the tumour. Both techniques are demanding and relatively expensive. However, IGRT is an irreplaceable technique in modern radiooncology and is used in IMRT, VMAT, SABR and particle therapy. It is important to note that not every patient is suitable for IGRT. It is indicated for the tumours that are positioned near the radiosensitive organs, where steep decrease of dose is required, abdominal and pelvical tumours where filling of organs (e.g. bladder, rectum) results in changes of anatomy, or in cases where dose escalation is needed. IGRT must be used rationally, because by using it exposes patient to extra radiation which amounts to between 0.1 and $3 \%$ of the treatment dose (18).

\section{Adaptive Radiotherapy}

Adaptive radiotherapy is an extension of IGRT. It's purpose is to modify and adjust the radiation plan during the treatment because of inevitable changes in anatomy caused by tumor shrinkage, changes in tumour biology, movement of adjacent organs, addition of chemotherapeutics or patients' weight loss. Replanning during the treatment is often demanding, especially by techniques such as VMAT and IMRT. This problem can be countered by taking potential changes in patients' anatomy into consideration before the therapy starts and make multiple treatment plans. Before the radiation process and on the daily basis, patients' anatomy is inspected by imaging methods and according to the patient anatomy, an optimal plan is chosen. During radiation of head and neck carcinomas as an example, parotid glands often move medially 4.2 millimetres towards the greater dose by average. Takings this into consideration, it is wise to replan patients (19).

It is well known in oncology that cancerous tissues are heterogeneous, formed from various clones that are a result from instability of tumour's genome. Heterogeneity of the tumour is an important factor in cancer re-emergence and progression. Various clones are differently sensitive to the radiation, therefore, inhomogeneous distribution of the dose on the cancerous tissue would be desirable. Using that as a premise, a new approach to radiotherapy has been formed, which integrates molecular and functional imaging with anatomical information. Two main strategies in achieving dose paintings are: dose painting by contours and dose painting by numbers. In former approach, within the target volume, areas of greater risk receive an extra boost. In the later approach, the dose is determined on the voxel level, therefore every individual voxel receives an individualized dose. Main focus of the dose painting procedure is on three proven causes of radiotherapeutic failures: tumour burden, hypoxia and tumour cell proliferation (20).

\section{Proton Therapy}

Radiotherapy with heavy particles, such as protons, neutrons and carbon ion is a very promising approach in therapy of malignant deseases. Most commonly used therapy with particles is the proton therapy, which is conducted in over 75 specialised centers across the world (21). The main advantages of the proton beams derive from their physical characteristics, where the proton of selected energy does not traverse the entire target, but stops at an exactly set depth. The maximum dose is applied just before the particle stops, which is known as Bragg's peak. According to it, steep fall of the dose to the 0 value can be seen. Proton beam does not have an exit dose and due to that fact, it completely conserves the healthy tissues distal to the target. Additionally, it has minimal lateral scattered dose (22). Current evidence suggests that there is a smaller number of acute and late side effects when using proton therapy in comparison to photon therapy (23). Proton therapy enables escalation of the dose, optimal preservation of healthy tissues and in extent, treatment of radioresistant tumours, such as: sarcomas, chondrosarcoma, uveal melanoma, skull base tumours, paraspinal tumours, paediatric tumours and reirradiation (24).

\section{Stereotactic Body Radiotherapy (SBRT)}

Stereotactic body radiotherapy (SBRT) or stereotactic ablative radiotherapy (SABR) is a new, 
non-invasive treatment, created by following the model of stereotactic radiosurgery (SRS) by gamma knife in treating brain metastases. Terms like SBRT and SARB are used to describe treatments of tumours outside the central nervous system, while the term SRS is used to describe the treatment of lesions within the central nervous system. SABR is based on highly conformal, high dose and precise beams, for the treatment of small tumours under imaging control. Unlike the classical fractional radiotherapy (3DCRT, IMRT, VMAT, IGRT), SABR enables hypofractionation, i.e. distribution of higher radiation dose within one or several fractions. This results in the reduction of therapy's duration from several weeks to few days (25). Development of today's SABR technique is enabled by modern linear accelerators, advanced imaging modality during the radiation, reproducible immobilizing systems and by using IMRT/VMAT planning techniques. All of the factors enabled the delivery of highly precise radioablative dose on the tumour, while sparing healthy tissues. If SABR technique is conducted precisely, side effects of grade 3 or higher are rare. It has been shown that they can occur in $15 \%$ of patients with lung cancer and $18 \%$ of patients with liver metastasis (26). Due to high dose within a fraction, possibility of rare and serious side effects has been described: fatal haemoptysis, bone fractures, myelopathy, plexopathy and chronic pain. SABR enabled the treatment of oligometastatic disease in extra and intracranial sites. Numerous non-randomised studies have shown that control rate of treated metastasis is $80 \%$ and $2-5$ year progression free survival of $20 \%$. SABR helps with postponing the progression and continuation of chemotherapy and also increases the quality of life (27). By using SABR technique, primary irradiation of low risk and intermediate risk prostate carcinomas has proven to be a successful, effective and safe method, as only $3 \%$ of treatment (among 500 patients) was unsuccessful (28). Studies have shown that patients with early stage, non-small cell lung cancer can be treated with SABR as an alternative to a radical surgical procedure. $70 \%$ of patients who were treated by SARB and $68 \%$ of patients who have undergone surgery survived for 2 years (29).

\section{CONCLUSION}

Radiotherapy is a branch of medicine that relies not only on medical knowledge, but also on knowledge in fields of chemistry, physics and biology. New techniques of radiotherapy have made great progress in local control of malignant deseases, in patient's survival, quality of life and treatment toxicity reduction. The outcome of malignant disease depends on many factors such as histopathological properties of the tumor, type and efficacy of the therapy, possible side effects etc. Considering all the above and the wide variety of different radiotherapy techniques and their specific physical and radiobiological properties, an individualized approach to each patient is important. In the future, we expect even more personalized approach based on the results of numerous investigations in the fields of tumour biology, biomarkers, tumour microenvironment, immunotherapy, combinations of therapies and further development in diagnostic and imaging technologies, bioinformatics and predictive models (30-32).

\section{REFERENCES}

1. Barton MB, Jacob S, Shafiq J, Wong K, Thompson SR, Hanna TP, Delaney GP. Estimating the demand for radiotherapy from the evidence: a review of changes from 2003 to 2012. Radiother Oncol. 2014;112(1): 140-144.

2. Bortfeld T, Boyer AL, Schlegel W, Kahler DL, Waldron TJ. Realization and verification of three-dimensional conformal radiotherapy with modulated fields. Int J Radiat Oncol Biol Phys. 1994;30(4):899-908.

3. Kamath S, Sahni S, Palta J, Ranka S. Algorithms for optimal sequencing of dynamic multileaf collimators. Phys Med Biol. 2004;49(1):33-54.

4. Bär W, Schwarz M, Alber M, Bos LJ, Mijnheer BJ, Rasch C, Schneider C, Nüsslin F, Damen EM. A comparison of forward and inverse treatment planning forintensity-modulated radiotherapy of head and neck cancer. Radiother Oncol. 200369(3):251-258.

5. Teh BS, Woo SY, Butler E. (1999). Intensity modulated radiation therapy (IMRT): A new promising technology in radiation oncology. The oncologist. 4:433-442.

6. Ghosh-Laskar S, Yathiraj PH, Dutta D, Rangarajan V, Purandare N, Gupta T,Budrukkar A, Murthy V, Kannan S, Agarwal JP. Prospective randomized controlled trial to compare 3-dimensional conformal radiotherapy to intensity-modulated radiotherapy in head and neck squamous cell carcinoma: Long-term results. Head Neck. 2016;38 Suppl 1:E1481-7.

7. Rehman J, Zahra, Ahmad N, Khalid M, Asghar HM, Gilani ZA, Ullah I, Nasar G, Akhtar M, Usmani MN. Intensity modulated radiation therapy: A review of current practice and future outlooks. Journal of Radiation Research and Applied Sciences. 2018;11(4): 361-367. 
8. Cheung K. Intensity modulated radiotherapy: advantages, limitations and future developments. Biomed Imaging Interv J. 2006;2(1):e19.

9. Otto K. Volumetric modulated arc therapy: IMRT in a single gantry arc. Med Phys. 2008;35(1):310-317.

10. Teoh M, Clark CH, Wood K, Whitaker S, Nisbet A. Volumetric modulated arc therapy: a review of current literature and clinical use in practice. Br J Radiol. 2011 Nov;84(1007):967-996.

11. Bertelsen A, Hansen CR, Johansen J, Brink C. Single Arc Volumetric Modulated Arc Therapy of head and neck cancer. Radiother Oncol. 2010;95(2):142-8.

12. Hall EJ, Wuu CS. Radiation-induced second cancers: the impact of 3D-CRT and IMRT. Int J Radiat Oncol Biol Phys. 2003;56(1):83-88.

13. Sterzing F, Kalz J, Sroka-Perez G, Schubert K, Bischof M, Roder F, Debus J, Herfarth K. Megavoltage CT in helical tomotherapy - clinical advantages and limitations of special physical characteristics. Technol Cancer Res Treat. 2009;8(5):343-352.

14. Sterzing F, Engenhart-Cabillic R, Flentje M, Debus J. Image-guided radiotherapy: a new dimension in radiation oncology. Dtsch Arztebl Int. 2011 Apr;108(16): 274-80.

15. Jensen AD, Grehn C, Nikoghosyan A, Thieke C, Krempien R, Huber PE, Debus J, Münter MW. Catch me if you can--the use of image guidance in the radiotherapy of an unusual case of esophageal cancer. Strahlenther Onkol. 2009;185(7):469-473.

16. Lee C, Langen KM, Lu W, Haimerl J, Schnarr E, Ruchala KJ, Olivera GH, Meeks SL, Kupelian PA, Shellenberger TD, Mañon RR. Assessment of parotid gland dose changes during head and neck cancer radiotherapy using daily megavoltage computed tomography and deformable image registration. Int J Radiat Oncol Biol Phys. 2008;71(5):1563-1571.

17. Guckenberger M, Krieger T, Richter A, Baier K, Wilbert J, Sweeney RA, Flentje M. Potential of imageguidance, gating and real-time tracking to improve accuracy in pulmonary stereotactic body radiotherapy. Radiother Oncol. 2009;91(3):288-295.

18. Sterzing, F., Engenhart-Cabillic, R., Flentje, M., \& Debus, J. (2011). Image-guided radiotherapy: a new dimension in radiation oncology. Deutsches Arzteblatt international, 108(16), 274-280.

19. Nishi T, Nishimura $Y$, Shibata T, Tamura M, Nishigaito $\mathrm{N}$, Okumura M. Volume and dosimetric changes and initial clinical experience of a two-step adaptive intensity modulated radiation therapy (IMRT) scheme for head and neck cancer. Radiother Oncol. 2013; 106(1):85-89.

20. Bentzen SM, Gregoire V. Molecular imaging-based dose painting: a novel paradigm for radiation therapy prescription. Semin Radiat Oncol. 2011;21(2):101-110.

21. "Particle therapy facilities in operation". PTCOG.ch. Particle Therapy Co-Operative Group. Sept 2019. Retrieved 2019-11-07.) at https://www.ptcog.ch/index. php/facilities-in-operation. Accessed on November 7th 2019.

22. Tian, X., Liu, K., Hou, Y., Cheng, J., \& Zhang, J. (2018). The evolution of proton beam therapy: Current and future status. Molecular and clinical oncology, 8(1), 15-21.

23. Chuong MD, Hallemeier CL, Jabbour SK, Yu J, Badiyan S, Merrell KW, Mishra MV, Li H, Verma V, Lin SH. Improving Outcomes for Esophageal Cancer using Proton Beam Therapy. Int J Radiat Oncol Biol Phys. 2016 May 1;95(1):488-497.

24. Hu, M., Jiang, L., Cui, X., Zhang, J., \& Yu, J. (2018). Proton beam therapy for cancer in the era of precision medicine. Journal of hematology \& oncology, 11(1), 136.

25. Sahgal A, Roberge D, Schellenberg D, Purdie TG, Swaminath A, Pantarotto J;The Canadian Association of Radiation Oncology-Stereotactic Body Radiotherapy Task Force. The Canadian Association of Radiation Oncology scope of practice guidelines for lung, liver and spine stereotactic body radiotherapy. Clin Oncol (R Coll Radiol). 2012 Nov;24(9):629-639.

26. Carey Sampson M, Katz A, Constine LS. Stereotactic body radiation therapy for extracranial oligometastases: does the sword have a double edge? Semin Radiat Oncol. 2006;16(2):67-76.

27. Tree AC, Khoo VS, Eeles RA, Ahmed M, Dearnaley DP, Hawkins MA, Huddart RA, Nutting CM, Ostler PJ, van As NJ. Stereotactic body radiotherapy for oligometastases. Lancet Oncol. 2013;14(1):e28-37.

28. Miszczyk L, Namysł-Kaletka A, Napieralska A, Kraszkiewicz M, Miszczyk M, Woźniak G, Tukiendorf A. Stereotactic Ablative Radiotherapy for Prostate Cancer-The Treatment Results of 500 Patients and Analysis of Failures. Technol Cancer Res Treat. 2019;18: 1533033819870815

29. Soldà F, Lodge M, Ashley S, Whitington A, Goldstraw $\mathrm{P}$, Brada M. Stereotactic radiotherapy (SABR) for the treatment of primary non-small cell lung cancer; systematic review and comparison with a surgical cohort. Radiother Oncol. 2013;109(1):1-7.

30. Yaromina, A., Krause, M., \& Baumann, M. (2012). Individualization of cancer treatment from radiotherapy perspective. Molecular oncology, 6(2), 211-221.

31. Valentini V, Dinapoli N, Damiani A. The future of predictive models in radiation oncology: from extensive data mining to reliable modeling of the results. Future Oncol. 2013;9(3):311-313.

32. Allen C, Her S, Jaffray DA. Radiotherapy for Cancer: Present and Future. Adv Drug Deliv Rev. 2017;109:1-2.

Corresponding author: Lidija Beketić-Orešković, Department of Clinical Oncology, School of Medicine University of Zagreb and Division of Radiotherapy and Medical Oncology, University Hospital for Tumors, Sestre milosrdnice University Hospital Center, Ilica 197, 10000 Zagreb, Croatia.e-mail: lidijabeketicoreskovic@gmail.com 